\title{
OPTIMALISASI TEGANGAN KELUARAN DARI SOLAR CELL MENGGUNAKAN LENSA PEMFOKUS CAHAYA MATAHARI
}

\author{
Oleh: \\ Faslucky Afifudin', Farid Samsu Hananto ${ }^{2}$
}

\begin{abstract}
ABSTRAK: Studi optimalisasi tegangan keluaran dari solar sel menggunakan lensa pemfokus cahaya matahari (lensa konvergen) bertujuan untuk mengetahui sebarapa besar pengaruh penggunaan lensa terhadap peningkatan nilai intensitas cahaya dan tegangan yang dihasilkan oleh solar sel, solar cell merupakan konverter energi cahaya menjadi energi listrik. Solar cell yang digunakan dalam penelitian ini adalah solar cell jenis policrystal dan amorphous.

Metode penelitian dilakukan dengan cara mengukur nilai intensitas, voltase dan arus listrik dari solar cell, kemudian menghitung nilai daya dan efisiensi dari solar cell dan membandingkan nilainya antara solar cell yang menggunakan lensa konvergen dan yang tidak menggunakan lensa konvergen.

Berdasarkan hasil data penelitian, lensa konvergen mempengaruhi besarnya daya dari cahaya yang digunakan, sehingga intensitas dan energi cahaya meningkat dan mempengaruhi nilai voltase dan arus listrik dari solar cell. Untuk solar cell jenis policrystal efisiensi dapat ditingkatkan sampai $35.08 \%$. Dan untuk solar cell jenis amorphous dapat ditingkatkan sampai $31.77 \%$.
\end{abstract}

Kata Kunci: Intensitas, Konvergen, Solar Cell, Policrystal, Amorphous.

\section{PENDAHULUAN}

Dalam era globalisasi dan modernisasi, setiap aspek kehidupan manusia tidak lepas dari sarana-sarana penunjang, baik dalam lingkungan rumah tangga maupun industri, dan setiap sarana memerlukan energi untuk dapat bekerja, dan dalam pemanfaatan energi diperlukan kebijakan dan pengaturan yang lebih baik dan terencana yang dikenal sebagai konservasi energi. Konservasi energi adalah penggunaan energi yang disertai usaha-usaha mencari teknologi baru dengan memanfaatkan sumber energi terbarui (misalnya sinar matahari, tenaga air dan panas bumi) dengan lebih efisien. Untuk jangka panjang, konservasi energi dapat menggunakan energi sedemikian rupa sehingga dapat menekan kerugian energi seminimal mungkin. Sedangkan untuk jangka pendek, konservasi energi dapat dilakukan melalui langkah-langkah penghematan energi maupun penggunaan energi yang terdapat di alam misalnya panas matahari.

Bila ditinjau dari sumber pengadaan energi saat ini. Sumber energi dunia masih sangat bergantung pada energi fosil, yang tidak dapat diperbarui lagi dengan jumlah sangat terbatas dan semakin lama semakin menipis serta pada suatu saat akan habis. Menurut Christ Lewis dalam bukunya yang berjudul Biological Fuels memperkirakan bahwa gas alam akan habis pada tahun 2047, minyak bumi pada tahun 2080, dan batu bara pada tahun 2180. Hal ini disebabkan karena energi fosil dieksplorasi secara besar-besaran dan tidak sebanding dengan waktu pembentukan energi fosil tersebut.

1,2 Jurusan Fisika Fakultas Sains dan Teknologi UIN Maliki Malang 
Indonesia merupakan salah satu negara yang beriklim tropis karena terletak dikawasan khatulistiwa, dan setiap tahunnya mendapat intensitas cahaya matahari lebih banyak dari pada di daerah selain daerah tropis. Untuk kawasan kepulauan yang tidak terdapat sungai-sungai besar sebagai sumber energi listrik, pembangkit tenaga surya merupakan salah satu alternatif untuk memenuhi kebutuhan energi listrik bagi kebutuhan penduduknya.

Dengan adanya fakta tersebut maka upaya-upaya pencarian sumber energi alternatif semakin banyak dilakukan. Dalam upaya pencarian sumber energi alternatif baru sebaiknya memenuhi syarat yaitu menghasilkan jumlah energi yang cukup besar, biaya ekonomis dan tidak berdampak negatif terhadap lingkungan. Berdasarkan pertimbangan tersebut, pencarian tersebut diarahkan pada pemanfaatan energi matahari. Untuk dapat memanfaatkan energi radiasi matahari dalam menghasilkan energi listrik, digunakan suatu perangkat yang dapat mengumpulkan energi radiasi matahari yang sampai ke permukaan bumi dan mengubahnya menjadi energi listrik. Perangkat ini disebut dengan panel surya atau solar cell.

\section{KAJIAN TEORI}

Matahari adalah bintang yang paling dekat dengan bumi, sehingga penelitian tentang bintang ini lebih mudah dari pada bintang lainnya. Matahari memiliki jarak 150 juta kilometer dari bumi, dan dia menyediakan energi yang dibutuhkan oleh kehidupan di bumi ini secara terus-menerus (Mulyono, 2007: 47). Energi yang dibebaskan oleh matahari setiap detinya menurut perhitungan para ahli, adalah ekuivalen dengan konversi massa hidrogen yang besarnya adalah $4,2 \times 10^{6}$ ton/detik, yang ekuivalen dengan $1,2 \times 10^{16} \mathrm{KW}$ (Daryanto, 2007: 72).

Energi yang diradiasikan akibat transformasi hidrogen menjadi helium yang kemudian menghasilkan energi

$$
4_{1} H_{1} \rightarrow 2 H e^{4}+2 e^{+}+\text {energi }
$$

Sebagian energi tersebut di transmisikan ke bumi dengan cara radiasi gelombang elektromagnetik. Radiasi menjalar dengan kecepatan cahaya $\left(3 \times 10^{8} \mathrm{~m} / \mathrm{s}\right)$ dalam bentuk gelombang yang mempunyai panjang gelombang yang berbeda-beda. Peristiwa ini akan berhenti jika hidrogen dalam reaksi inti habis (Daryanto, 2007: 72).

Solar cell atau sel photovoltaic, adalah sebuah alat semikonduktor yang terdiri dari sebagian besar dioda $\mathrm{p}-\mathrm{n}$ junction dan dengan adanya cahaya matahari mampu menciptakan energi listrik. Perubahan ini disebut efek photovoltaic. Bidang riset berhubungan dengan sel surya dikenal sebagai photovoltaics (Patel, 2006: 143).

Berdasarkan jenis dan bentuk susunan atom-atom penyusunnya, solar cell dapat dibedakan menjadi 3 jenis, yaitu (Patel, 2006: 153): 


\section{Monokristal (Mono-crystalline)}

Merupakan panel yang paling efisien yang dihasilkan dengan teknologi terkini dan menghasilkan daya listrik persatuan luas yang paling tinggi. Monokristal dirancang untuk penggunaan yang memerlukan konsumsi listrik besar pada tempat-tempat yang beriklim ekstrim dan dengan kondisi alam yang sangat ganas. Memiliki efisiensi sampai dengan 14 - 18\%. Kelemahan dari panel jenis ini adalah tidak akan berfungsi baik ditempat yang cahaya mataharinya kurang (teduh), sehingga efisiensinya akan turun drastis dalam cuaca berawan.

\section{Polikristal (Poly-crystalline)}

Merupakan panel surya yang memiliki susunan kristal acak karena dipabrikasi dengan proses pengecoran. Tipe ini memerlukan luas permukaan yang lebih besar dibandingkan dengan jenis monokristal untuk menghasilkan daya listrik yang sama. Panel suraya jenis ini memiliki efisiensi lebih rendah dibandingkan tipe monokristal, sehingga memiliki harga yang cenderung lebih rendah (Patel, 2006: 153).

\section{Amorphous}

"Amorf" mengacu pada objek memiliki bentuk yang pasti dan tidak ada didefinisikan sebagai bahan non-kristal. Tidak seperti silikon kristal, di mana susunan atom yang teratur, fitur silikon amorf pengaturan atomnya tidak teratur seperti yang ditunjukkan pada gambar di bawah ini. Sehingga, aktivitas timbal balik antara foton dan atom silikon lebih sering terjadi pada silikon amorf dibandingkan kristal silikon, memungkinkan lebih banyak cahaya yang dapat diserap. Dengan demikian, sebuah film silikon amorf yang sangat tipis yang kurang dari $1 \mu \mathrm{m}$ dapat diproduksi dan digunakan untuk pembangkit listrik. Selain itu, dengan memanfaatkan logam atau plastik untuk substrat, sel surya fleksibel juga dapat diproduksi.

Solar cell jenis amorphous adalah solar cell yang dibentuk dengan mendoping material silikon di belakang lempeng kaca. Dinamakan amorphous atau tanpa bentuk karena material silikon yang membentuknya tidak terstruktur atau tidak mengkristal. Solar cell jenis ini biasanya berwarna coklat tua pada sisi yang menghadap matahari dan keperakan pada sisi konduktifnya. Pada solar cell jenis ini terdapat garis-garis tipis pararel di permukaannya, garis-garis ini merupakan lapisan $n$ dan $p$ dari substrat silikon dan menjadi batas-batas individu solar cell dalam panel. Solar cell jenis ini biasanya tanpa titik hook-up atau kabel yang jelas, sehingga dapat membingungkan untuk menggunakannya (Pagliaro, 2008: 62).

Sel surya konvensional, misalnya p-n , memiliki energi gap (Eg), ketika sel terkena spektrum matahari, sebuah foton dengan energi kurang dari Eg, tidak akan membuat kontribusi terhadap out put sel (mengabaikan Fonon yang membantu penyerapan). Sedangkan sebuah foton dengan energi lebih besar dari Eg, akan memberikan kontribusi sebesar energi Eg ke out put sel, dan energi yang terlalu besar dari pada Eg akan terbuang menjadi panas. Untuk memperoleh efisiensi konversi yang ideal, harus dipertimbangkan besarnya energi. (Sze, 1981: 403). 


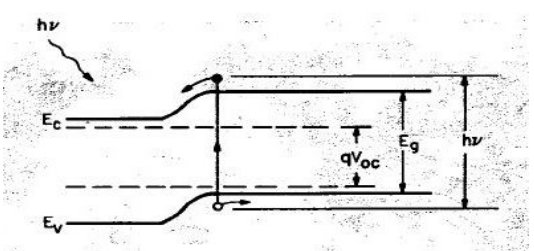

Gambar 1. Energi Gap

(sumber: Physics of Semiconductor Devices Second Edition)

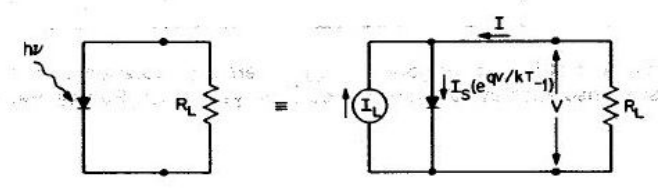

Gambar 2. Skema Rangkaian Tertutup pada Solar Cell (sumber: Physics of Semiconductor Devices Second Edition)

Diagram pita p-n di bawah radiasi matahari. Tampilkan dalam Gambar. 1 sel surya diasumsikan memiliki karakteristik $I$ dan $V$ yang ideal. Rangkaian ekuivalen ditunjukkan pada Gambar. 2 Dimana sumber arus konstan di pararel dengan persimpangan (sambungan). Sumber arus $\mathrm{I}_{\mathrm{L}}$ adalah hasil eksitasi berlebih yang dibawa oleh radiasi matahari. IS adalah arus saturasi diode dan $R_{L}$ adalah resistansi beban. Karakteristik $I$ dan $V$ dari rangkaian tersebut adalah (Sze, 1981: 403 - 404):

$$
\mathrm{I}=\mathrm{I}_{\mathrm{S}}\left(\mathrm{e}^{\frac{\mathrm{qV}}{\mathrm{kT}}}-1\right)-\mathrm{I}_{\mathrm{L}}
$$

dan

$$
\mathrm{J}_{\mathrm{S}}=\frac{\mathrm{I}_{\mathrm{S}}}{\mathrm{A}}=\mathrm{qN}_{\mathrm{C}} \mathrm{N}_{\mathrm{V}}\left(\frac{1}{\mathrm{~N}_{\mathrm{A}}} \sqrt{\frac{\mathrm{D}_{\mathrm{N}}}{\tau_{\mathrm{N}}}}+\frac{1}{\mathrm{~N}_{\mathrm{D}}} \sqrt{\frac{\mathrm{D}_{\mathrm{P}}}{\tau_{\mathrm{P}}}}\right) \mathrm{e}^{\frac{-\mathrm{Eg}}{\mathrm{kT}}}
$$

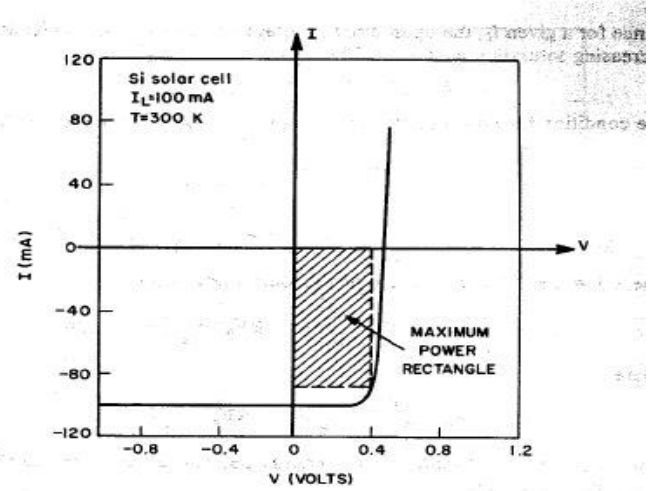

Gambar 3. Grafik Daya pada Solar Cell (sumber: Physics of Semiconductor Devices Second Edition) 


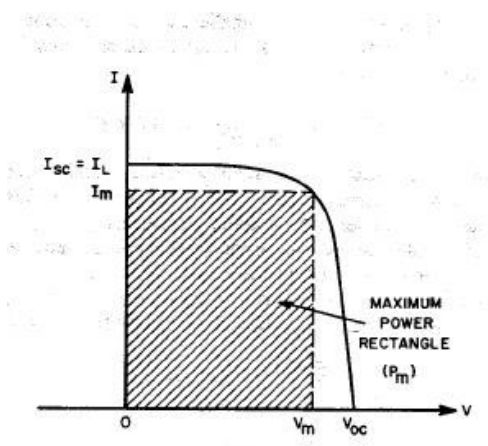

Gambar 4. Grafik Daya Maksimum pada Solar Cell (sumber: Physics of Semiconductor Devices Second Edition)

Dimana A adalah luas daerah, plot A dari persamaan (1) ditunjukkan pada Gambar. 3 untuk $I_{L}=100 \mathrm{~mA}$ dan $I_{S}=1 \mathrm{nA}$ luas wilayah $A=4 \mathrm{~cm} 2$ dan $T=300 \mathrm{~K}$. Kurva melewati ke empat kuadran dan oleh karena itu daya dapat dihasilkan dari rangkaian ini. Dengan pemilihan yang benar, mendekati $80 \% I_{S C}-V_{O C}$ dapat dihasilkan ( $I_{S C}$ adalah arus short circuit dan $V_{O C}$ adalah tegangan open circuit dari solar cell, dan daerah yang diasir adalah luas daya maksimum). Kurva I-V umumnya ditunjukkan oleh Gambar. 4 dimana kurva tersebut adalah inverse dari Gambar. 3 dengan sumbu tegangan. Kita juga mendefinisikan pada Gambar. Kuantitas Im dan Vm yang masing-masing adalah arus dan tegangan maksimum untuk daya keluaran maksimum. $(\mathrm{Pm}=\mathrm{ImVm})$. Dari persamaan (1) kita peroleh tegangan untuk rangkaian terbuka $(I=0)($ Sze, 1981: 404):

$$
\mathrm{V}_{\mathrm{OC}}=\frac{\mathrm{kT}}{\mathrm{q}} \ln \left(\frac{\mathrm{I}_{\mathrm{L}}}{\mathrm{I}_{\mathrm{S}}}+1\right) \approx \frac{\mathrm{kT}}{\mathrm{q}} \ln \left(\mathrm{I}_{\mathrm{L}} / \mathrm{I}_{\mathrm{S}}\right)
$$

Tegangan open circuit meningkat secara logaritma dengan menurunnya arus saturasi, maka daya keluarannya adalah (Sze, 1981: 406):

$$
P=I V=\mathrm{I}_{\mathrm{S}} \mathrm{V}\left(\mathrm{e}^{\frac{\mathrm{qV}}{\mathrm{kT}}}-1\right)-\mathrm{I}_{\mathrm{L}} \mathrm{V}
$$

Keadaan daya maksimum dapat diperoleh jika $\mathrm{dP} / \mathrm{dV}=0$, atau

$$
\begin{aligned}
& \mathrm{I}_{\mathrm{m}}=\mathrm{I}_{\mathrm{S}} \beta \mathrm{V}_{\mathrm{m}} \mathrm{e}^{\beta \mathrm{V}_{\mathrm{m}}} \approx\left(1-/ \beta \mathrm{V}_{\mathrm{m}}\right) \ldots \ldots \ldots \ldots \ldots \ldots \ldots \ldots \\
& \mathrm{V}_{\mathrm{m}}=\frac{1}{\beta} \ln \left(\frac{\frac{\mathrm{I}_{\mathrm{L}}}{\mathrm{I}_{\mathrm{S}}}}{1-\beta \mathrm{V}_{\mathrm{m}}}\right) \approx \mathrm{V}_{\mathrm{OC}}-\frac{1}{\beta} \ln \left(1+\beta \mathrm{V}_{\mathrm{m}}\right)
\end{aligned}
$$

Dimana $\beta=\mathrm{q} / \mathrm{kT}$, maka daya maksimum keluaran adalah (Sze, 1981: 406):

$$
\begin{aligned}
& \mathrm{P}_{\mathrm{m}}=\mathrm{I}_{\mathrm{m}} \mathrm{V}_{\mathrm{m}} \approx \mathrm{I}_{\mathrm{L}}\left[\mathrm{V}_{\mathrm{OC}}-\frac{1}{\beta} \ln \left(1+\beta \mathrm{V}_{\mathrm{m}}\right)-\frac{1}{\beta}\right]=\mathrm{I}_{\mathrm{L}}\left(\mathrm{E}_{\mathrm{m}} / \mathrm{q}\right)(7) \\
& \text { Dimana } E_{m}=q\left[V_{O C}-\frac{1}{\beta} \ln \left(1+\beta V_{m}\right)-\frac{1}{\beta}\right]
\end{aligned}
$$

Energi $\mathrm{E}_{\mathrm{m}}$ ini berhubungan dengan energi per foton yang diambil pada titik maksimum. Maka efisiensi ideal dari solar cell adalah (Sze, 1981: 406):

$$
\dot{\eta}=\frac{\mathrm{P}_{\mathrm{m}}}{\mathrm{P}_{\mathrm{In}}}=\left[\mathrm{V}_{\mathrm{m}}^{2} \mathrm{I}_{\mathrm{S}}\left(\frac{\mathrm{q}}{\mathrm{kT}}\right) \mathrm{e}^{\frac{\mathrm{q} \mathrm{V}_{\mathrm{m}}}{\mathrm{kT}}}\right] / \mathrm{P}_{\text {In }}
$$

efisiensi maksimum yang diperoleh yaitu $31 \%$ untuk $\mathrm{Eg}=1.35 \mathrm{eV}$ dengan menggunakan parameter sifat bahan semikonduktor dari III - V. 
Efisiensi sel surya $\eta$ juga dapat dinyatakan dengan perbandingan antara daya listrik maksimum sel surya atau daya output yang dikeluarkan sel surya dengan daya pancaran (radiant) atau daya input yang berasal dari cahaya matahari pada sel surya:

$$
\begin{aligned}
& \eta=\frac{\text { I x V }}{\text { intensitas cahaya x Luas Panel }} \times 100 \% \\
& \dot{\eta}=\frac{\mathrm{P}}{\mathrm{G} \times \mathrm{A}} \times 100 \%
\end{aligned}
$$

$\eta \dot{~ m e n u n j u k k a n ~ n i l a i ~ e f i s i e n s i ~ d a l a m ~ p e r s e n ~(\%), ~} \mathrm{P}$ adalah daya output yang dihasilkan sel surya. $\mathrm{G}$ menunjukkan Intensitas irradiasi matahari dalam $\mathrm{W} / \mathrm{m}^{2}$ dan A menunjukkan luas permukaan modul sel surya dalam $\mathrm{m}^{2}$.

\section{METODE PENELITIAN}

Metode dalam penelitian ini adalah menguji dua jenis solar cell (policrystal dan amorf) dengan dua keadaan, yaitu dengan tidak menggunakan lensa konvergen dan yang menggunakan lensa konvergen, kemudian membandingkan hasil pengukuran antara solar cell yang tidak menggunakan lensa konvergen dengan yang menggunakan lensa konvergen dan menghitung daya dan efisiensi yang dihasilkan oleh masing-masing solar cell.

Adapun langkah-langkah dalam pengambilan data dalam penelitian ini adalah sebagai berikut:

\section{Penelitian di Dalam Ruangan}

1. Penelitian dilakukan didalam ruangan (laboratorium) untuk menghindari pengaruh cahaya matahari.

2. Merangkai alat dan memasang semua alat ukur seperti termometer untuk mengukur suhu. Luxmeter untuk mengukur intensitas cahaya dan multimeter untuk mengukur voltase dan arus listrik.

3. Memasang dan menyalakan lampu halogen sebagai sumber cahaya.

4. Pengambilan data intensitas cahaya, voltase dan arus listrik dengan variasi jarak untuk mengubah nilai intensitas cahaya.

5. Melakukan pencatatan beberapa parameter-parameter di atas.

D. Penelitian di Luar Ruangan

6. Merangkai alat dan memasang semua alat ukur seperti termometer untuk mengukur suhu. Luxmeter untuk mengukur intensitas cahaya dan multimeter untuk mengukur voltase dan arus listrik.

7. Pengambilan data intensitas cahaya dilakukan secara periodik yaitu dilakukan setiap selang 5 menit dan 1 menit.

8. Pengambilan data voltase dan arus listrik dengan variasi waktu untuk mengetahui perbedaan nilainya.

9. Melakukan pencatatan beberapa parameter-parameter di atas. 
Parameter yang diukur akan dibuat dalam bentuk tabulasi data. Untuk mengetahui daya dan efisiensi, akan dianalisis dari pengukuran intensitas cahaya, luas permukaan solar cell, voltase dan arus listrik. Untuk mengukur daya solar cell, digunakan persamaan:

$$
\begin{gathered}
P=V I \\
\eta=\frac{P}{\mathrm{G} \times \mathrm{A}} \times 100 \%
\end{gathered}
$$

Dimana: $P$ adalah daya solar cell (Watt)

$G$ adalah Intensitas Cahaya (Lux atau Watt/m2)

$A$ adalah Luas Penampang ( $m 2)$

$\dot{\eta}$ adalah efisiensi solar cell $(\%)$

\section{HASIL DAN PEMBAHASAN}

Penelitian yang dilakukan di dalam laboratorium merupakan salah satu cara untuk mendapatkan data dengan nilai kesalahan atau error yang kecil, hal ini dikarenakan di dalam laboratorium, sumber cahaya yang digunakan berasal dari lampu halogen dan dapat dikondisikan sedemikian rupa sehingga menjaga intensitas cahaya yang digunakan agar tetap konstan dan tidak berubah-ubah secara drastis seperti pada penelitian di luar laboratorium yang mengunakan sumber cahaya yang berasal dari matahari.

Pada tabel 1 menunjukkan bahwa intensitas yang besar memberikan nilai voltase dan arus yang besar pula. Pada intensitas 9120 Lux, solar cell policrystal menghasilkan voltase 2.73 volt dan arus $3.48 \mathrm{~mA}$ sedangkan untuk solar cell jenis amorphous menghasilkan voltase 5.97 volt dan arus $0.929 \mathrm{~mA}$. Voltase dan arus menurun seiring berkurangnya intensitas cahaya yang mengenai permukaan solar cell.

Tabel 1. Intensitas voltase dan arus listrik solar cell tanpa lensa konvergen

\begin{tabular}{|c|c|c|c|c|c|}
\hline \multirow{3}{*}{$\begin{array}{c}\text { Suhu } \\
\left({ }^{\circ} \mathbf{C}\right)\end{array}$} & $\begin{array}{c}\text { Intensitas } \\
(\text { Lux })\end{array}$ & $\begin{array}{c}\text { Voltase } \\
(\text { Volt })\end{array}$ & $\begin{array}{c}\text { Voltase } \\
(\text { Volt) }\end{array}$ & Arus (mA) & Arus (mA) \\
\hline \multirow{7}{*}{25} & 9120 & 2.73 & 5.97 & 3.48 & 0.929 \\
\cline { 2 - 6 } & 3600 & 2.47 & 5.73 & 2.04 & 0.555 \\
\cline { 2 - 6 } & 2040 & 2.33 & 5.58 & 1.36 & 0.332 \\
\cline { 2 - 6 } & 1390 & 2.16 & 5.5 & 0.91 & 0.223 \\
\cline { 2 - 6 } & 1020 & 1.97 & 5.39 & 0.469 & 0.162 \\
\cline { 2 - 6 } & 775 & 1.79 & 5.31 & 0.356 & 0.122 \\
\cline { 2 - 6 } & 601 & 1.64 & 5.23 & 0.288 & 0.096 \\
\cline { 2 - 6 } & 488 & 1.53 & 5.15 & 0.228 & 0.077 \\
\hline
\end{tabular}


Pada tabel 2 menunjukkan perubahan intensitas terhadap daya dan efisiensi yang dihasilkan solar cell. Pada tabel 4.2 daya terbesar dihasilkan oleh intensitas terbesar pula, yaitu pada intensitas 9120 Lux, daya dari solar cell policrystal adalah $9.5 \mathrm{mWatt}$ dan 5.5 mWatt pada solar cell amorphous. Sedangkan efisiensi terbesar terjadi pada intensitas 2040 Lux, yaitu sebesar $41.95 \%$ pada solar cell policrystal dan $36.78 \%$ pada solar cell amorphous.

Tabel 2. Intensitas, daya dan efisiensi solar cell tanpa lensa konvergen

\begin{tabular}{|c|c|c|c|c|c|}
\hline \multirow{4}{*}{$\begin{array}{c}\text { Suhu } \\
\left({ }^{\circ} \mathbf{C}\right)\end{array}$} & $\begin{array}{c}\text { Intensitas } \\
(\mathbf{L u x})\end{array}$ & $\begin{array}{c}\text { Daya } \\
(\mathbf{m W a t t})\end{array}$ & $\begin{array}{c}\text { Efisiensi } \\
(\%)\end{array}$ & $\begin{array}{c}\text { Daya } \\
(\mathbf{m W a t t})\end{array}$ & $\begin{array}{c}\text { Efisiensi } \\
(\%)\end{array}$ \\
\cline { 2 - 6 } & 9120 & 9.5004 & 28.1345683 & 5.54613 & 24.6365374 \\
\cline { 2 - 6 } & 3600 & 5.0388 & 37.8022651 & 3.18015 & 35.7873521 \\
\cline { 2 - 6 } & 2040 & 3.1688 & 41.9525018 & 1.85256 & 36.789728 \\
\cline { 2 - 6 } & 1390 & 1.9656 & 38.1921007 & 1.2265 & 35.7468036 \\
\cline { 2 - 6 } & 1020 & 0.92393 & 24.4642609 & 0.87318 & 34.6807172 \\
\cline { 2 - 6 } & 775 & 0.63724 & 22.2072371 & 0.64782 & 33.8639108 \\
\cline { 2 - 6 } & 601 & 0.47232 & 21.2253601 & 0.50208 & 33.8440955 \\
\cline { 2 - 6 } & 488 & 0.34884 & 19.3063271 & 0.39655 & 32.9202098 \\
\hline
\end{tabular}

Pada tabel 3. nilai arus listrik terbesar pada solar cell jenis polycrystal dan amorphous terletak pada nilai intensitas yang berbeda, voltase terbesar pada solar cell jenis policrystal yaitu 2.66 volt dan 0.407 volt untuk solar cell amorphous pada intensitas 12000 Lux sedangkan untuk arus listrik solar cell policrystal adalah adalah $2.07 \mathrm{~mA}$ pada intensitas 12000 Lux dan untuk solar cell amorphous adalah $0.428 \mathrm{~mA}$ pada intensitas $0.428 \mathrm{~mA}$. Pada kolom pertama, nilai voltase lebih kecil pada intensitas cahaya yang lebih besar, hal ini dikarenakan permukaan solar cell tidak sepenuhnya mendapatkan cahaya.

Tabel 3. Intensitas, voltase dan arus listrik solar cell menggunakan lensa konvergen dengan jarak $10 \mathrm{~cm}$ dari sumber cahaya

\begin{tabular}{|c|c|c|c|c|c|}
\hline \multirow{2}{*}{$\begin{array}{c}\text { Suhu } \\
\left({ }^{\circ} \mathbf{C}\right)\end{array}$} & $\begin{array}{c}\text { Intensitas } \\
(\text { Lux })\end{array}$ & $\begin{array}{c}\text { Voltase } \\
(\text { Volt })\end{array}$ & Arus (mA) & $\begin{array}{c}\text { Poltase } \\
\text { (Volt) }\end{array}$ & Arus (mA) \\
\cline { 3 - 6 } & 33400 & 2.25 & 0.72 & 0.027 & 0.012 \\
\hline \multirow{3}{*}{25} & 12000 & 2.66 & 2.07 & 0.407 & 0.267 \\
\cline { 2 - 6 } & 5620 & 2.54 & 1.47 & 0.372 & 0.428 \\
\cline { 2 - 6 } & & & & &
\end{tabular}




\begin{tabular}{|c|c|c|c|c|c|}
\cline { 2 - 5 } 3160 & 2.43 & 1.28 & 0.283 & 0.381 \\
\cline { 2 - 6 } & 1990 & 2.35 & 1.17 & 0.222 & 0.294 \\
\hline 1400 & 2.21 & 0.98 & 0.168 & 0.229 \\
\hline 1040 & 2.14 & 0.81 & 0.134 & 0.186 \\
\hline
\end{tabular}

Pada tabel 4 menunjukkan perubahan intensitas terhadap daya dan efisiensi yang dihasilkan solar cell. Daya terbesar yaitu pada intensitas 12000 Lux, pada solar cell policrystal adalah $5.506 \mathrm{mWatt}$ dan pada solar cell amorphous pada intensitas 5620 Lux dengan daya sebesar 0.159 mWatt. Sedangkan efisiensi terbesar pada solar cell policrystal adalah pada intensitas 1040 Lux dengan efisiensi sebesar $45.01 \%$ dan pada solar cell amorphous terjadi pada intensitas 3160 Lux, yaitu sebesar $1.38 \%$.

Tabel 4. Intensitas, daya dan efisiensi solar cell menggunakan lensa konvergen dengan jarak $10 \mathrm{~cm}$ dari sumber cahaya

\begin{tabular}{|c|c|c|c|c|c|}
\hline \multirow{4}{*}{$\begin{array}{c}\text { Suhu } \\
\left({ }^{\circ} \mathbf{C}\right)\end{array}$} & $\begin{array}{c}\text { Intensitas } \\
(\text { Lux })\end{array}$ & $\begin{array}{c}\text { Daya } \\
(\mathbf{m W a t t})\end{array}$ & $\begin{array}{c}\text { Efisiensi } \\
(\%)\end{array}$ & $\begin{array}{c}\text { Daya } \\
(\mathbf{m W a t t})\end{array}$ & $\begin{array}{c}\text { Efisiensi } \\
(\%)\end{array}$ \\
\hline \multirow{4}{*}{25} & 33400 & 1.62 & 1.30997121 & 0.000324 & 0.00039299 \\
\cline { 2 - 6 } & 12000 & 5.5062 & 12.392643 & 0.108669 & 0.3668672 \\
\cline { 2 - 6 } & 5620 & 3.7338 & 17.9435322 & 0.159216 & 1.14771711 \\
\cline { 2 - 6 } & 3160 & 3.1104 & 26.5841246 & 0.107823 & 1.38232063 \\
\cline { 2 - 6 } & 1990 & 2.7495 & 37.315894 & 0.065268 & 1.32871455 \\
\cline { 2 - 6 } & 1400 & 2.1658 & 41.7814509 & 0.038472 & 1.11327175 \\
\cline { 2 - 6 } & 1040 & 1.7334 & 45.0151453 & 0.024924 & 0.9708874 \\
\cline { 2 - 6 } & 800 & 1.2338 & 41.6531626 & 0.016157 & 0.81819195 \\
\hline
\end{tabular}

Tabel 5 menunjukkan perbandingan antara intensitas cahaya, voltase, arus listrik, daya dan efisiensi yang dihasilkan oleh solar cell yang tidak menggunakan lensa konvergen dengan yang menggunakan lensa konvergen dengan jarak konstan $45 \mathrm{~cm}$ dari sumber cahaya. Daya yang dihasilkan sebelum menggunakan lensa konvergen adalah 0.45 mWatt dengan efisiensi $20.26 \%$ dan setelah menggunakan lensa konvergen, dayanya meningkat menjadi $2.58 \mathrm{mWatt}$ dengan efisiensinya $35.38 \%$. 
Tabel 5. Intensitas, voltase, arus dan daya solar cell policrystal dengan jarak $45 \mathrm{~cm}$ dari sumber cahaya

\begin{tabular}{|l|l|l|l|l|l|}
\hline $\begin{array}{c}\text { Intensitas } \\
(\text { Lux })\end{array}$ & $\begin{array}{c}\text { Voltas } \\
\text { e (Volt) }\end{array}$ & $\begin{array}{c}\text { Arus } \\
(\mathbf{m A})\end{array}$ & $\begin{array}{c}\text { Daya } \\
(\mathbf{m W a t t})\end{array}$ & Efisiensi (\%) & \multicolumn{1}{|c|}{ Keterangan } \\
\hline 601 & 1.64 & 0.275 & 0.451 & 20.26727093 & Tanpa lensa \\
\hline 1990 & 2.35 & 1.1 & 2.585 & 35.08331915 & $\begin{array}{l}\text { Jarak sumber cahaya } \\
\text { dengan lensa 10 cm dan } \\
\text { jarak lensa dengan solar } \\
\text { cell 35 cm }\end{array}$ \\
\hline 651 & 1.67 & 0.356 & 0.59452 & 24.66486165 & $\begin{array}{l}\text { Jarak sumber cahaya } \\
\text { dengan lensa 15 cm dan } \\
\text { jarak lensa dengan solar } \\
\text { cell 30 cm }\end{array}$ \\
\hline 602 & 1.54 & 0.318 & 0.48972 & 21.97073333 & $\begin{array}{l}\text { Jarak sumber cahaya } \\
\text { dengan lensa 20 cm dan } \\
\text { jarak lensa dengan solar } \\
\text { cell 25 cm }\end{array}$ \\
\hline 494 & 1.36 & 0.224 & 0.30464 & 16.65532766 & $\begin{array}{l}\text { Jarak sumber cahaya } \\
\text { dengan lensa 25 cm dan } \\
\text { jarak lensa dengan solar } \\
\text { cell 20 cm }\end{array}$ \\
\hline
\end{tabular}

Tabel 6 menunjukkan perbandingan antara intensitas cahaya, voltase, arus listrik, daya dan efisiensi yang dihasilkan oleh solar cell yang tidak menggunakan lensa konvergen dengan yang menggunakan lensa konvergen dengan jarak konstan $45 \mathrm{~cm}$ dari sumber cahaya. Daya yang dihasilkan sebelum menggunakan lensa konvergen adalah 0.5 mWatt dengan efisiensi $33.84 \%$ dan setelah menggunakan lensa konvergen, dayanya meningkat menjadi $1.26 \mathrm{mWatt}$ dengan efisiensinya $25.85 \%$.

Tabel 6. Intensitas, voltase, arus dan daya solar cell amorphous dengan jarak $45 \mathrm{~cm}$ dari sumber cahaya

\begin{tabular}{|l|l|l|l|l|l|}
\hline $\begin{array}{l}\text { Intensitas } \\
(\text { Lux })\end{array}$ & $\begin{array}{l}\text { Voltase } \\
(\text { Volt })\end{array}$ & $\begin{array}{l}\text { Arus } \\
(\mathbf{m A})\end{array}$ & $\begin{array}{l}\text { Daya } \\
(\mathbf{m W a t t})\end{array}$ & Efisiensi (\%) & Keterangan \\
\hline 601 & 5.23 & 0.096 & 0.50208 & 33.84409552 & Tanpa lensa \\
\hline 1990 & 5.72 & 0.222 & 1.26984 & 25.85118104 & $\begin{array}{l}\text { Jarak sumber cahaya } \\
\text { dengan lensa 10 cm dan } \\
\text { jarak lensa dengan solar } \\
\text { cell 35 cm }\end{array}$ \\
\hline 651 & 5.49 & 0.093 & 0.51057 & 31.77303979 & $\begin{array}{l}\text { Jarak sumber cahaya } \\
\text { dengan lensa 15 cm dan }\end{array}$ \\
\hline
\end{tabular}




\begin{tabular}{|l|l|l|l|l|l|}
\hline & & & & & $\begin{array}{l}\text { jarak lensa dengan solar } \\
\text { cell } 30 \mathrm{~cm}\end{array}$ \\
\hline 602 & 5.58 & 0.062 & 0.34596 & 23.28165554 & $\begin{array}{l}\text { Jarak sumber cahaya } \\
\text { dengan lensa 20 cm dan } \\
\text { jarak lensa dengan solar } \\
\text { cell 25 cm }\end{array}$ \\
\hline 494 & 5.57 & 0.058 & 0.32306 & 26.49358335 & $\begin{array}{l}\text { Jarak sumber cahaya } \\
\text { dengan lensa 25 cm dan } \\
\text { jarak lensa dengan solar } \\
\text { cell 20 cm }\end{array}$ \\
\hline
\end{tabular}

Untuk mengetahui seberapa besar pengaruh intensitas terhadap voltase dan arus listrik solar cell, maka diperlukan data-data di luar laboratorium. Berdasarkan data yang diperoleh, nilai intensitas dan arus listrik solar cell di luar laboratorium jauh lebih besar dari data yang diperoleh di dalam laboratorium, sedangkan untuk nilai voltasenya tidak jauh berbeda dari data yang diperoleh di dalam laboratorium. Berikut ini merupakan tabel data hasil penelitian yang dilakukan di luar laboratorium.

Tabel 7. Voltase solar cell setiap jangka waktu 5 menit

\begin{tabular}{|c|c|c|c|}
\hline \multirow{2}{*}{ Waktu } & \multirow{2}{*}{$\begin{array}{c}\text { Intensitas } \\
(\text { Lux })\end{array}$} & Policrystal & Amorf \\
\cline { 3 - 4 } & 91200 & 3.03 & 6.23 \\
\hline $10: 15$ & 91500 & 3.11 & 6.41 \\
\hline $10: 20$ & 95000 & 3.06 & 6.38 \\
\hline $10: 25$ & 94200 & 3.05 & 6.45 \\
\hline $10: 30$ & 11300 & 2.73 & 6.25 \\
\hline $10: 35$ & 85900 & 3.05 & 6.53 \\
\hline $10: 40$ & 89100 & 3.02 & 6.52 \\
\hline $10: 45$ & 40000 & 2.88 & 6.35 \\
\hline $10: 50$ & & & \\
\hline
\end{tabular}


Tabel 8. Voltase solar cell setiap jangka waktu 1 menit

\begin{tabular}{|l|l|l|l|}
\hline \multirow{2}{*}{ Waktu } & \multirow{2}{*}{$\begin{array}{l}\text { Intensitas } \\
(\text { Lux })\end{array}$} & Poltase (Volt) & Amorf \\
\cline { 3 - 4 } & & Policrystal & 6.38 \\
\hline $11: 00$ & 9200 & 2.71 & 6.44 \\
\hline $11: 01$ & 9600 & 2.76 & 6.72 \\
\hline $11: 02$ & 15600 & 2.92 & 7.01 \\
\hline $11: 03$ & 86400 & 3.21 & 6.64 \\
\hline $11: 04$ & 23400 & 2.87 & 6.74 \\
\hline $11: 05$ & 23800 & 2.95 & 7.13 \\
\hline $11: 06$ & 86000 & 3.19 & \\
\hline
\end{tabular}

Data - data diatas merupakan data nilai intensitas dan voltase dari solar cell, berdasarkan data di atas, nilai intensitas dan voltase berubah - ubah, hal ini dikarenakan keadaan di luar laboratorium sulit dikendalikan karena banyak faktor yang mempengaruhi intensitas cahaya matahari. Sedangkan untuk data arus listrik, daya serta efisiensi solar cell dilampirkan pada tabel di bawah ini:

Tabel 9. Daya dan Efisiensi solar cell jenis polycristal dengan sumber cahaya matahari

\begin{tabular}{|c|c|c|c|c|c|}
\hline Suhu $\left({ }^{\circ} \mathbf{C}\right)$ & $\begin{array}{c}\text { Intensitas } \\
(\text { Lux })\end{array}$ & $\begin{array}{c}\text { Voltase } \\
(\text { Volt })\end{array}$ & $\begin{array}{c}\text { Arus } \\
(\mathbf{m A})\end{array}$ & $\begin{array}{c}\text { Daya } \\
(\mathbf{m W a t t})\end{array}$ & $\begin{array}{c}\text { Efisiensi } \\
(\boldsymbol{\%})\end{array}$ \\
\hline 29 & 90700 & 3.14 & 14.4 & 45.216 & 13.464123 \\
\hline 29 & 88900 & 3.1 & 14.19 & 43.989 & 13.363971 \\
\hline 29 & 88900 & 3.12 & 14.21 & 44.3352 & 13.469148 \\
\hline
\end{tabular}

Tabel 10. Daya dan Efisiensi solar cell jenis amorphous dengan sumber cahaya matahari

\begin{tabular}{|c|c|c|c|c|c|}
\hline Suhu $\left({ }^{\circ} \mathbf{C}\right)$ & $\begin{array}{c}\text { Intensitas } \\
(\mathbf{L u x})\end{array}$ & $\begin{array}{c}\text { Voltase } \\
(\text { Volt) }\end{array}$ & $\begin{array}{c}\text { Arus } \\
(\mathbf{m A})\end{array}$ & $\begin{array}{c}\text { Daya } \\
(\mathbf{m W a t})\end{array}$ & $\begin{array}{c}\text { Efisiensi } \\
(\mathbf{\%})\end{array}$ \\
\hline 29 & 83200 & 6.35 & 0.995 & 6.31825 & 3.0765072 \\
\hline 29 & 76900 & 6.35 & 0.889 & 5.64515 & 2.9739496 \\
\hline 29 & 81100 & 6.35 & 0.621 & 3.94335 & 1.9698308 \\
\hline
\end{tabular}

Cahaya matahari membawa paket-paket energi sebagaimana dijelaskan dalam teori kuantum yang dicetuskan oleh Planck, prinsip dari solar cell adalah efek photovoltaic, prinsip ini mirip seperti efek fotolistrik, persamaan prinsip ini adalah elektron akan berpindah apabila menyerap energi dalam tingkat-tingkat tertentu. Pada efek photovoltaic, elektron akan berpindah dari pita valensi ke pita konduktif sehingga menghasilkan arus 
listrik. Berdasarkan teori, banyaknya elektron yang berpindah bergantung pada intensitas cahaya yang diserapnya, sedangkan besarnya energi dari setiap elektron yang lepas ini bergantung pada frekuensi cahaya yang diserap oleh elektron.

Pada penelitian ini digunakan lensa konvergen yang berfungsi meningkatkan intensitas cahaya, besarnya intensitas dipengaruhi oleh daya dari cahaya, pemberian lensa ini akan meningkatkan daya persatuan luas, apabila daya meningkat maka energi yang diterima setiap elektron juga akan meningkat, karena energi juga dipengaruhi oleh daya, semakin besar energi yang diserap elektron maka semakin besar pula voltase yang dihasilkan. Voltase merupakan perbandingan antara jumlah energi yang dibutuhkan untuk memindahkan muatan dari suatu titik ke titik lain dengan besarnya muatan yang dipindahkan. Jadi peningkatan daya dengan memberikan lensa konvergen dapat meningkatkan energi yang diterima setiap elektron, dan elektron yang berpindah ini akan menyebabkan timbulnya arus listrik dan beda potensial.

Berdasarkan data penelitian, solar cell jenis polycristal menunjukkan voltase atau beda potensialnya tidak melebihi nilai 4 volt walaupun intensitasnya telah diperbesar, hal ini sama dengan apa yang terjadi pada solar cell jenis amorphous, nilainya tidak lebih dari 8 volt, hal ini menunjukkan bahwa elektron pada solar cell memiliki batas ambang, sehingga walaupun intensitasnya diperbesar, voltasenya tidak akan melebihi batas ambangnya. Elektron pada solar cell hanya menyerap foton pada tingkat-tingkat energi tertentu, sedangkan besarnya voltase akan mempengaruhi arus listrik, namun pada kondisi tertentu nilai arusnya akan konstan dan tidak bergantung pada besarnya beda potensial atau voltase.

Perbedaan nilai voltase pada solar cell jenis policrystal dan amorphous disebabkan oleh perbedaan jenis ikatan pada molekul - molekulnya, sehingga mempengaruhi besarnya energi ikat pada elektron valensinya, pada solar cell policrystal, energi ikat pada elektronnya lebih besar dari pada solar cell jenis amorphous, sehingga untuk intensitas cahaya yang sama voltase yang dihasilkan oleh solar cell jenis policrystal lebih kecil dari pada solar cell jenis amorphous karena jumlah energi gap yang digunakan oleh elektron untuk berpindah dari pita valensi ke pita konduksi jauh lebih besar pada solar cell jenis policrystal dari pada solar cell jenis amorphous.

Perbedaan nilai arus listrik pada solar cell jenis policrystal dan solar cell jenis amorphous juga dipengaruhi oleh jenis ikatan dari molekul - molekul pembentuknya, perbedaan jenis ikatan ini mempengaruhi struktur yang dibentuk oleh molekul - molekul solar cell. Pada solar cell jenis policrystal, struktur molekulnya lebih rapi dan tertata, sedangkan pada solar cell jenis amorphous letaknya tidak teratur. Arus listrik timbul akibat muatan yang bergerak, apabila muatan yang bergerak tersebut membawa energi yang besar, maka untuk waktu yang sama, daya yang dihasilkan juga besar, jika voltase konstan maka besarnya akan bergeser ke arah arus listriknya, besarnya energi ini bergantung pada rintangan yang dilaluinya. Untuk struktur kristal yang teratur dan rapi, maka elektron tidak akan banyak kehilangan energi, berbeda dengan struktur amorf yang 
strukturnya tidak teratur, elektron akan lebih banyak kehilangan energi, sehingga daya dan arus listriknya akan lebih kecil dari pada struktur kristal.

\section{KESIMPULAN}

Berdasarkan hasil data penelitian, lensa konvergen mempengaruhi besarnya daya dari cahaya yang digunakan, sehingga intensitas dan energi cahaya meningkat dan mempengaruhi nilai voltase dan arus listrik dari solar cell. Untuk solar cell jenis policrystal efisiensi dapat ditingkatkan sampai 35.08\%. Dan untuk solar cell jenis amorphous dapat ditingkatkan sampai $31.77 \%$.

\section{DAFTAR PUSTAKA}

Daryanto. 2007. Energi Masalah dan Pemanfaatannya Bagi Kehidupan Manusia. Yogyakarta: Pustaka Widyatama

Pagliaro, Mario. 2008. Flexible Solar Cells. Weinheim: WILEY-VCH Verlag GmbH \& Co. KGaA.

Patel. Mukund R. 2006. Wind and Solar Power Systems Design, Analysis, and Operation. USA: Taylor \& Francis Group, LLC.

Sze, S.M. 1981. Physics of Semiconductor Devices Second Edition. Canada: John Wiley \& Son, Inc 